\title{
P-glycoprotein Inhibitor
}

National Cancer Institute

\section{Source}

National Cancer Institute. P-glycoprotein Inhibitor. NCI Thesaurus. Code C114757.

Any compound or agent that acts to prevent the activity of P-glycoprotein. 